\title{
TINDAK TUTUR ILOKUSI KOMUNITAS PATENG KABUPATEN MANGGARAI BARAT DI SURABAYA
}

\author{
Ignasius Randun, Agung Pramujiono, Ira Eko Retnosari \\ (pendidikan Bahasa dan Sastra Indonesia, Fakultas Keguruan dan Ilmu Pendidikan, \\ Universitas PGRI Adi Buana Surabaya) \\ custosranos@gmail.com, Agungpramujiono.unipasby@gmail.com, \\ Ira_eko_80@yahoo.com
}

\begin{abstract}
ABSTRAK
Penelitian ini bertujuan untuk; Mendeskripsikan jenis-jenis tindak tutur ilokusi yang terdapat pada masyarakat tutur Pateng di Surabaya, dan Mendeskripsikan fungsi ilokusi yang terdapat pada percakapan masyarakat Pateng di Surabaya. Sumber data penelitian adalah masyarakat Pateng di Surabaya. Semua ilokusi tuturan yang digunakan oleh masyarakat Pateng di Surabaya menjadi objek penelitian ini. Pengumpulan data dari hasil metode refer. Data dianalisis dengan metode unified untuk memperoleh gambaran tindak tutur dan fungsi ilokusi. Validitas yang digunakan dalam penelitian ini adalah validitas semantik. Uji reliabilitas dilakukan dengan membaca berulang-ulang dan diskusi dengan teman sekelas dan dosen. Hasil penelitian ini menunjukkan bahwa: 1) ditemukan dalam empat jenis tindak tutur ilokusi yang sering digunakan oleh masyarakat Pateng di Surabaya, yaitu tindak tutur asertif, tindak tutur direktif, tindak tutur komisif, dan tindak tutur ekspresif, 2) terdapat pada empat fungsi ilokusi. digunakan oleh komunitas Pateng di Surabaya, fungsionalitas yang kompetitif, konvivial, kolaboratif dan konfliktif.
\end{abstract}

Kata kunci: Dialog komunitas pateng, tindak tutur, ilokusi

\section{PENDAHULUAN}

Bahasa merupakan salah satu hal utama dalam berkomunikasi. Bahasa sebagai alat komunikasi mempunyai peran penting bagi manusia karena dengan bahasa manusia dapat mengeskpresikan apa yang ada dalam pikiran atau gagasannya. Jika bahasa yang digunakan manusia dikaitkan dengan penutur dan mitra tutur maka akan terbentuk suatu tindak tutur dan peristiwa tutur. Tindak tutur sebagai wujud peristiwa komunikasi bukanlah peristiwa yang terjadi dengan sendirinya, melainkan mempunyai fungsi, mengandung maksud, dan tujuan tertentu serta dapat menimbulkan pengaruh atau akibat pada mitra tutur.

Teori tindak tutur diperkenalkan pertama kali oleh John Austin pada tahun 1955 di Universitas Harvard, yang kemudian dibukukan pada tahun 1962 dengan judul "How to do things with words". John Austin menyatakan bahwa tindak tutur merupakan konsep teori yang menyatakan bahwa pada dasarnya apabila seseorang mengatakan sesuatu maka sebenarnya dia juga melakukan sesuatu (Nadar, 2009:256).

Dengan bahasa, manusia dapat mengekpresikan semua yang ada dalam pikiran karena dengan berpikir secara otomatis manusia menuturkan suatu bahasa di dalam pikirannya. Hal tersebut antara lain dapat dilihat pada seorang sastrawan karena ia dapat mengekspresikan perasaannya ada kalanya menggunakan bahasa yang berupa percakapan atau tuturan. 
Pada dasarnya, tindak tutur yang dihasilkan bergantung pada tujuan atau arah tuturan untuk mencapai tujuan, tindak tutur harus disesuaikan dengan situasi tuturan. Situasi tuturan tersebut merupakan situasi sosial yang aktual karena terjadi dalam lingkungan masyarakat yang luas dan berbeda. Jadi, situasi tutur dapat mempengaruhi tercapai tujuan tuturan. Bahasa memungkinkan dapat membangun kebudayaan serta menguasai ilmu pengetahuan dan dengan demikian meningkatkan mutu kehidupannya. Bahasa juga dapat mempengaruhi arah prilaku manusia. Tindak tutur (speech act) adalah gejala individu yang bersifat psikologis dan berlangsungnya ditentukan oleh kemampuan bahasa di penutur dalam menghadapi situasi tertentu.

Menurut Chaer dalam Rahmadi (1995:65), jika peristiwa tutur (speech event) merupakan gejala social dan terdapat interaksi antara penutur dalam situasi dan tempat tertentu, maka tindak tutur (speech acts) lebih cenderung sebagai gejala individual, bersifat psikologis dan ditentukan oleh kemampuan bahasa penutur dalam mnghadapi situasi tertentu. Lebih lanjut dijelaskan bahwa jika dalam peristiwa maka dalam tindak tutur orang lebih memperhatikan makna atau arti tindak dalam tuturan itu.

Pragmatik erat sekali hubungannya dngan tindak ujar atau tindak tutur. Pragmatik menelaah ucapan-ucapan khususnya dalam situasi khususnya terutama memusatkan perhatian pada aneka ragam cara yang merupakan aneka konteks sosial performasi bahasa mempengaruhi tafsiran atau interpretasi. Levinson (dalam Tarigan, 1996:33), memberi batasan pragmatik adalah telaah mengenai kemampuan pemakaian bahasa menghubungkan serta menyerasikan kalimat-kalimat dan konteks secara tepat. Kata bahasa itu menggarap kesatuan statis yang abstrak seperti dalam sintaksis dan proposisi dalam semantik. Pragmatik menggarap bahasa dalam tingkat yang lebih konkrit tindakan dalam mengatakan sesuatu, misalnya mengucapkan kata-kata tertentu dengan perasaan dan referensi atau acuan tertentu. Dalam Kamus Besar Bahasa Indonesia disebutkan bahwa kata tindak berarti langkah perbuatan, sedangkan kata tutur berarti ucapan, kata, perkataan.

Dalam praktik penggunaan bahasa, Searle (1969:23-24) membagi tindak tutur menjadi tiga macam. Ketiga macam tindak tutur tersebut adalah (1) tindak tutur lokusi (locutionary acts), (2) tindak tutur ilokusi (illocutionary acts), dan (3) tindak tutur perlokusi (perlocutionary acts). Tindak lokusi adalah tindak tutur untuk menyatakan sesuatu, sedangkan tindak ilokusi adalah tindakan yang ingin dicapai oleh penutur pada waktu menuturkan sesuatu dan dapat merupakan tindakan menyatakan, berjanji, minta maaf, dan lain sebagainya. Tindak ilokusi dapat dikatakan tindak tutur terpenting dalam kajian tindak tutur karena tindak tutur ilokusi membicarakan tentang maksud dan fungsi tuturan yang diujarkan serta untuk apa tuturan itu diujarkan. Tindak tutur ilokusi juga berkaitan dengan siapa bertutur kepada siapa, kapan, dan di mana tindak tutur tersebut dilakukan. Tindak tutur perlokusi adalah tuturan yang diucapkan oleh penutur yang mempunyai efek atau daya pengaruh terhadap mitra tutur, seperti pada contoh tuturan berikut. 
(1) A: "Aku haus."

B: "Ya sebentar."

Dalam contoh tuturan (1) di atas, tindak lokusi dalam kalimat A jika diutarakan oleh seseorang yang bertamu di rumah temannya dimaksudkan untuk menginformasikan sesuatu tanpa bermaksud untuk mempengaruhi mitra tutur. Tindak ilokusi dalam kalimat A jika diutarakan oleh seseorang yang bertamu di rumah temannya pada waktu siang hari yang amat panas, maka ilokusinya adalah untuk meminta minum kepada mitra tuturnya. Tindak perlokusi dalam kalimat A adalah agar mitra tutur memberikan reaksi dengan cara memberikan minuman kepada penutur. Dalam peristiwa tutur, ketiga macam tindak tutur tersebut diorganisasi secara sistematis untuk menyampaikan gagasan atau untuk mencapai tujuan dalam hal berkomunikasi. Tujuan tersebut merupakan isi pembicaraan yang dilakukan oleh penutur dan mitra tutur.

Ketiga macam tindak tutur tersebut di atas juga dapat ditemukan dalam keseharian komunitas pateng yang ada di Surabaya. Pesan komunikasi dalam sebuah komunitas dapat diwujudkan dalam tindak tutur, yaitu melalui percakapan yang diutarakan oleh orang-orang yang berada dalam suatu komunitas. Sebagai contoh dapat dilihat pada salah satu contoh percakapan komunitas pateng yang ada di Surabaya.

\section{METODE PENELITIAN}

Dalam penelitian ini, digunakan pendekatan kualitatif karena data penelitian berupa bentuk-bentuk verbal bahasa yaitu berupa tuturan yang dilakukan oleh komunitas
Pateng Kabupaten Manggarai Barat di Surabaya. Selain pendekatan kualitatif juga digunakan pendekatan deskriptif. Pendekatan tersebut adalah suatu pendekatan yang berupaya mengungkapkan sesuatu secara apa adanya (Sudaryanto, 1992:62). Pada penelitian ini yang dilakukan sematamata hanya berdasarkan pada fakta yang ada atau fenomena yang secara empiris hidup pada penuturnya, sehingga yang dihasilkan berupa bahasa yang biasa dilakukan sifatnya.

Dalam penelitian ini,Teknik penelitian yang digunakan adalah teknik sadap, yaitu penyimakan dilakukan dengan menyimak setiap percakapan yang digunakan komunitas pateng yang ada di Surabaya. Peneliti mendengarkan dan merekam untuk memperoleh transkrip dialog.

\section{HASIL DAN PEMBAHASAN \\ A. Hasil Penelitian}

Hasil penelitian ini berupa deskripsi jenis dan fungsi tindak tutur ilokusi yang terdapat dalam komunitas pateng yang ada di Surabaya, yaitu tindak tutur asertif, direktif, komisif, dan ekspresif.

Jenis tindak tutur ilokusi yang ditemukan dalam penelitian ini terbagi menjadi lima jenis, yaitu tindak tutur asertif, direktif, komisif, dan ekspresif. Berikut akandipaparkan secara berurutan jenis tindak tutur ilokusi yang terdapat dalam komunitas pateng yang ada di Surabaya

a. Tindak Tutur Asertif

Pada ilokusi ini, penutur terikat pada kebenaran tuturan yang diutarakan.

b. Tindak Tutur Direktif

Pada ilokusi ini, penutur mengharapkan suatu tindakan 
dari mitra tutur yang diinginkan oleh penutur.

c. Tindak Tutur Komisif

Pada ilokusi ini, penutur terikat untuk melaksanakan apa yang disebutkan pada tuturannya.

d. Tindak Tutur Ekspresif

Pada ilokusi ini, penutur mengekspresikan,

mengungkapkan

atau

memberitahukan

sikap

psikologisnya terhadap keadaan yang tersirat dalam ilokusi.

Hasil penelitian menunjukkan bahwa fungsi tindak tutur ilokusi yang ditemukan dalam tuturan komunitas pateng yang ada di Surabaya adalah fungsi kompetitif, konvivial, kolaboratif, dan konfliktif.

a. Fungsi Kompetitif

Pada dasarnya tujuan yang bersifat kompetitif ini bersifat tidak sopan karena dapat merepotkan, menyusahkan dan merugikan mitra tutur.

b. Fungsi Konvivial

Pada fungsi konvivial, kesopansantunan digunakan dalam mencari berbagai kesempatan untuk bersikap hormat seperti mengucapkan terimakasih, mengucapkan selamat, memuji, dan lain-lain

c. Fungsi Kolaboratif

Pada fungsi kolaboratif, tujuan penutur untuk menyatakan, melapor, mengumumkan dan mengajarkan suatu informasi kepada mitra tutur

d. Fungsi Konfliktif

Pada fungsi konfliktif, tujuan fungsi ilokusi ini bertentangan dengan tujuan sosial yaitu dengan menimbulkan atau menyebabkan suatu perdebatan antara penutur dengan mitra tutur.

\section{B. Pembahasan}

Persamaan pada penelitian ini sama-sama meneliti mengenai tindak tutur ilokusi. Perbedaan pada penelitian ini peneliti meneliti mengenai tindak tutur dalam komunitas sedangkan penelitian Bowo Setyoanto (2015) meneliti tentang Dialog film. Persamaan pada penelitian ini sama-sama meneliti mengenai tindak tutur. Persamaan jumlah jenis tindak tutur ilokusi yaitu sama-sama memiliki 5 jenis tindak tutur ilokusi.

a. Tindak Tutur Asertif

Pada ilokusi ini, penutur terikat pada kebenaran tuturan yang diutarakan.

b. Tindak Tutur Direktif

Pada ilokusi ini, penutur mengharapkan suatu tindakan dari mitra tutur yang diinginkan oleh penutur.

c. Tindak Tutur Komisif

Pada ilokusi ini, penutur terikat untuk melaksanakan apa yang disebutkan pada tuturannya.

d. Tindak Tutur Ekspresif

Pada ilokusi ini, penutur mengekspresikan,

mengungkapkan atau memberitahukan sikap psikologisnya terhadap keadaan yang tersirat dalam ilokusi.

\section{SIMPULAN}

Berdasarkan hasil analisis data penelitian yang diperoleh, dapat diambil simpulan bahwa tindak tutur ilokusi komunitas pateng kabupaten Manggarai Barat di Surabaya sebagai berikut.

1. Jenis tindak tutur ilokusi yang ditemukan pada percakapan komunitas pateng yang ada di 
Surabaya adalah tindak tutur asertif, direktif, komisif, dan ekspresif. Tindak tutur asertif yang ditemukan dalam tuturan komunitas pateng terjadi pada tuturan yang mengikat penutur akan kebenaran informasi yang diutarakan seperti tuturan untuk menyatakan, memberitahukan dan melaporkan kepada mitra tutur. Tindak tutur direktif yang ditemukan dalam tuturan komunitas pateng terjadi pada tuturan penutur agar mitra tutur melakukan tindakan yang diinginkan oleh penutur seperti tuturan requestives, questions, requirements, dan advisories. Tindak tutur komisif yang ditemukan dalam tuturan komunitas pateng terjadi pada tuturan yang mengikat penuturnya untuk melaksanakan apa yang disebutkan dalam tuturannya seperti tuturan menawarkan, berjanji, dan bersumpah. Tindak tutur ekspresif yang ditemukan dalam tuturan komunitas pateng terjadi pada tuturan penutur untuk mengekspresikan,

mengungkapkan atau memberitahukan sikap psikologis penutur kepada mitra tutur seperti tuturan untuk mengucapkan terima kasih, memohon maaf, mengucapkan selamat, mengucapkan bela sungkawa, kesal atau jengkel dan memuji.

Pada tuturan komunitas pateng tidak ditemukan tindak tutur berjenis deklaratif. Hal ini dapat terjadi karena dalam percakapan tidak ditemukan tuturan dari penutur yang dimaksudkan untuk menciptakan hal (status, keadaan, dan sebagainya) yang baru. Misalnya, menyerahkan diri, memecat, membebaskan, membaptis, memberi nama, menamai, mengucilkan, mengangkat, menunjuk, menentukan, menjatuhkan hukuman, menvonis, dan sebagainya.

2. Fungsi ilokusi yang ditemukan dalam tuturan komunitas pateng adalah fungsi kompetitif, konvivial, kolaboratif, dan konfliktif. Fungsi kompetitif yang ditemukan dalam komunitas pateng terjadi pada tuturan penutur yang tidak sopan seperti memaksa mitra tutur untuk melakukan sesuatu atau tuturan penutur dapat merepotkan, menyusahkan, dan merugikan mitra tutur.

Fungsi konvivial yang ditemukan dalam tuturan komunitas pateng yang ada di Surabaya pada tuturan yang mempunyai makna untuk menyenangkan mitra tutur seperti menawarkan, mengucapkan selamat dan mengucapkan terima kasih. Fungsi kolaboratif yang ditemukan dalam tuturan komunitas pateng yang ada di Surabaya terjadi pada tuturan yang ditujukan untuk menyatakan, melapor, dan memberitahukan suatu informasi kepada mitra tutur.

Fungsi konfliktif yang ditemukan dalam tuturan komunitas pateng yangnada di Surabaya terjadi pada tuturan yang bertentangan dengan norma sosial dalam masyarakat seperti mengancam, menegur, dan mengomeli mitra tutur atas tindakan mitra tutur kepada penutur.

\section{SARAN}

Dari hasil penelitian ini, saran yang perlu diperhatikan adalah:

1. Bagi mahasiswa, disarankan bahwa penelitian ini digunakan untuk meningkatkan 
pengetahuan, pemahaman dan wawasan tentang ilmu pragmatik, khususnya tentang tindak tutur ilokusi dan fungsi tindak tutur ilokusi serta implementasinya dalam kehidupan sehari-hari.

2. Bagi peneliti selanjutnya, disarankan agar lebih memahami dan menyempurnakan penelitian tindak tutur ilokusi ini dengan mengambil salah satu jenis tindak tutur ilokusi agar cakupan penelitian tidak terlalu luas. Peneliti selanjutnya juga dapat mengkaji tentang bentuk lokusi, bentuk ilokusi dan bentuk perlokusi yang terdapat pada tuturan komunitas pateng yang ada di Surabaya.

\section{DAFTAR PUSTAKA}

Bowo, Setyoanto. 2015. Skripsi: Tindak Tutur Ilokusi Dialog Film $5 \mathrm{~cm}$ Karya Rizal
Mantovani ( Sebuah Tinjauan Pragmatik)

Chaer, Abdul. 2010. Sosiolinguistik: Perkenalan Awal. Jakarta: PT Rineka Cipta.

Muhajir, Noeng. 2000. Metodologi Penelitian Kualitatif. Yogyakarta: Rake Sarasir.

Nadar, F.X.2009. Pragmatik dan Penelitian Pragmatik. Yogyakarta: Graha Ilmu.

Rohmadi, Muhammad. 2004. Pragmatik Teori dan Analisis. Yogyakarta: Lingkar Media Yogyakarta.

Searle, dkk. 1980. Kepragmatisan Wacana. Bandung : CV Yrama Widya.

Sudaryanto. 1993. Metode dan Teknik Analisis Bahasa. Yogyakarta: Duta Wacana.

Tarigan, Henry Guntur. 1986. Pengajaran Pragmatik. Bandung: Angkasa Bandung. 